\title{
ATTIS ON OGYGIA: CATULLUS' CARMEN 63 AND THE ODYSSEY
}

\begin{abstract}
Scholars have long noticed a similarity of motifs between Catullus' Carmen 63 and the fifth book of the Odyssey, where the story of Odysseus' captivity on Ogygia is narrated. A detailed analysis of the poems shows that Catullus wanted the reader to see in this Homeric episode a kind of matrix for the interpretation of Attis' sojourn at Cybele. The discovery of this dependence casts a light on some of the hitherto proposed interpretations of Carmen 63.
\end{abstract}

Keywords: Catullus; Attis; Cybele; Homer; Odysseus; Calypso; hubris

Catullus' Carmen $63,{ }^{1}$ the only ancient poem written in the galliambic metre that is preserved in its entirety, is considered by some scholars to be one of the most difficult to interpret in all of Latin poetry. ${ }^{2}$ The content of the poem is as follows: Attis, accompanied by a group of his followers, crosses the sea to reach Mt Ida in the Troad, where the goddess Cybele has her sanctuary. As soon as his feet touch the mainland, Attis performs an act of self-castration. He calls for his companions, who have also castrated themselves, to follow him through the woods to Cybele's shrine. When they arrive there, exhausted by Bacchic frenzy, they fall into a deep sleep. As Attis awakes with the sunrise, he realizes the horror of the deed he had committed the day before. Attis runs back to the shore, where he delivers a monologue full of pain and longing for his homeland. Cybele, however, hears his lamentations and sends a lion after him. At the sight of the beast Attis falls again into a frenzy and hurriedly returns to Cybele's wilderness, where he will remain her servant for the rest of his life. The poem ends with an apostrophe to Cybele in which the poet begs her to keep her fury far away from his home.

\section{CARMEN 63 AND THE ODYSSEY: STATVS QVAESTIONIS AND ARGUMENT OF THE ARTICLE}

Scholars have long noticed that in the scene where Attis is lamenting at the seashore there are elements which are analogous to the scene in the Odyssey, where Odysseus, imprisoned by Calypso and filled with longing for Penelope and his native Ithaca, sits on the seashore staring at the sea:

${ }^{1}$ I use the edition of Catullus by D.F.S. Thomson, Catullus. Edited with a Textual and Interpretative Commentary (Toronto, 1997) and the translation (with occasional changes) by F.W. Cornish, Catullus, Tibullus and Pervigilium Veneris (London, 1962).

${ }^{2}$ E.g. S. Harrison, 'Altering Attis: ethnicity, gender and genre in Catullus 63', Mnemosyne 57 (2004), 520-33, at 520; J.S. Clay, 'Catullus' "Attis" and the Black Hunter', QUCC 50 (1995), $143-55$, at 143 .

(C) The Author(s), 2021. Published by Cambridge University Press on behalf of The Classical Association. This is an Open Access article, distributed under the terms of the Creative Commons Attribution licence (http://creativecommons.org/licenses/by/4.0/), which permits unrestricted re-use, distribution, and reproduction in any medium, provided the original work is properly cited. 
animo aestuante rusum reditum ad uada tetulit.

ibi maria uasta uisens lacrimantibus oculis

patriam allocuta maestast ita uoce miseriter. (Catull. 63.47-9)

$\ldots$

at ubi umida albicantis loca litoris adiit,

teneramque uidit Attin prope marmora pelagi

facit impetum. (63.87-9)

With surging mind again he sped back to the waves. There, looking out upon the waste seas with streaming eyes, thus did she piteously address her country with tearful voice. ... But when he [sc. Cybele's lion] came to the watery stretches of the white-gleaming shore, and saw tender Attis by the smooth spaces of the sea, he rushes at him.

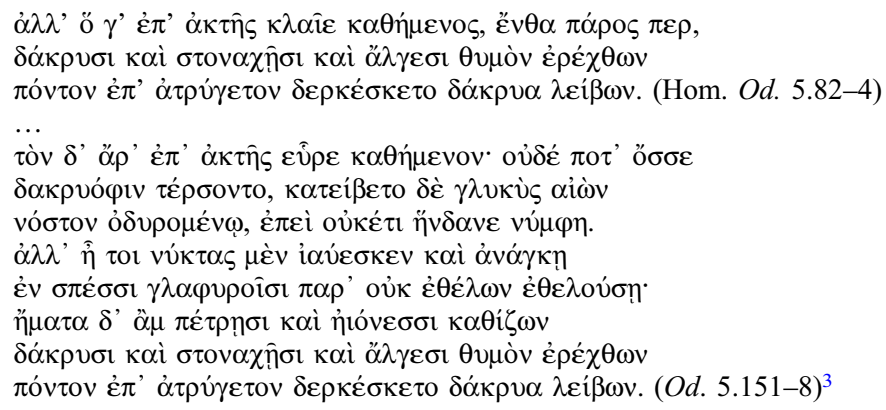

But he was sitting out on the beach, crying, as before now he had done, breaking his heart in tears, lamentation and sorrow as, weeping tears, he looked out over the barren water ... And [sc. Calypso] found him sitting on the seashore, and his eyes were never wiped dry of tears, and the sweet lifetime was draining out of him, as he wept for a way home, since the nymph was no longer pleasing to him. By nights he would lie beside her, of necessity, in the hollow caverns, against his will, by one who was willing, but all the days he would sit upon the rocks, at the seaside, breaking his heart in tears and lamentation and sorrow as, weeping tears, he looked out over the barren water.

Scholars have juxtaposed the following: the two protagonists' stay at the seashore (Harder, Clay, Syndikus); the desire they both shared to get out of the place of their captivity (Harder); their longing for their homeland (Clay, Syndikus); their gazing at the sea with their eyes full of tears (Clay, Syndikus); the important role played by a goddess in the context of the whole scene (Fedeli). ${ }^{4}$ Moreover, Rubino noticed a psychological analogy of the situation in which the two protagonists found themselves. ${ }^{5}$ The evident parallels between Carmen 63 and the Odyssey have, however, hitherto not been the subject of any deeper analysis: to my knowledge neither a monograph nor a chapter in a book nor even a paragraph in an article has been devoted to this

\footnotetext{
${ }^{3}$ I use the edition of the Odyssey by P. von der Mühll, Homerus Odyssea (Stuttgart, $1984^{3}$ ) and the translation (with occasional changes) by R. Lattimore, The Odyssey of Homer (Chicago, 1996).

${ }^{4}$ A. Harder, 'Catullus 63: A “Hellenistic poem”?', Mnemosyne 57 (2004), 574-95, at 588; Clay (n. 2), 153; H.P. Syndikus, Catull: Eine Interpretation: Die grossen Gedichte (61-68) (Darmstadt, 1990), 90 n. 66; P. Fedeli, 'Struttura e stile dei monologhi di Attis nel carme 63 di Catullo', RFIC 106 (1978), 39-52, at 52.

${ }^{5}$ C.A. Rubino, 'Myth and mediation in the Attis poem of Catullus', Ramus 3 (1974), 152-75, at $165,166,168$.
} 
issue. I have also found no mention of these parallels neither in the scholarly commentaries on Catullus' poems ${ }^{6}$ nor in articles discussing the issue of Catullus' references to Homeric poems. ${ }^{7}$

In the present article I will, first, try to show that Carmen 63 presents Attis' story through the prism of Odysseus' stay at Ogygia. ${ }^{8}$ Subsequently, I will try to show that, owing to the discovery of the reference to the Odyssey, some previous interpretations of Carmen 63, in particular those of Clay ${ }^{9}$ and Nauta, ${ }^{10}$ who saw in Attis' journey to Cybele an escape from human marriage, and of Näsström, ${ }^{11}$ according to whom Attis' emasculation was done to attain divine immortality, find new support. Moreover, in the light of Näsström's interpretation, Attis' drastic deed can be seen as an act of hubris and, hence, his metamorphosis into an androgynous being can be seen as its dramatic consequence.

\section{THE DEPENDENCE OF CARMEN 63 ON THE ODYSSEY}

Since some of the parallels between Carmen 63 and the Odyssey have so far not been noticed by scholars, it is appropriate to provide a comprehensive comparison of the situations experienced by Attis and by Odysseus on Ogygia. The parallels are as follows:

1. Both Odysseus and Attis find themselves alone on the seashore: $\dot{\alpha} \lambda \lambda$ ' ö $\gamma^{\prime}$ ' $\varepsilon$ '

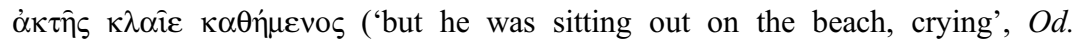

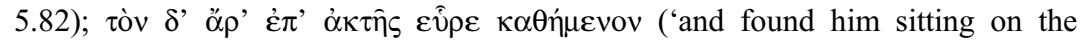
seashore', Od. 5.151); at ubi umida albicantis loca litoris adiit, | teneramque uidit Attin prope marmora pelagi ('but when he came to the watery stretches of the white-gleaming shore, and saw tender Attis by the smooth spaces of the sea', Catull. 63.87-8). They are both found (عîpe/uidit) by inland residents (Calypso and the lion, the messenger of Cybele), who are responsible for their imprisonment.

\footnotetext{
${ }^{6}$ K. Kokoszkiewicz, 'C. Valerii Catulli carmina prolegomenis, apparatu critico commentarioque instructa' (Diss., University of Warsaw, 2013); D.H. Garrison, The Student's Catullus (Norman, $2004^{4}$ ); Thomson (n. 1); F. Della Corte, Catullo: Le poesie (Milan, 1977); W. Kroll, C. Valerius Catullus (Stuttgart, 1968); C.J. Fordyce, Catullus. A Commentary (Oxford, 1961); G. Friedrich, Catulli Veronensis liber (Leipzig, 1908); E.T. Merrill, Commentary on Catullus (Cambridge, 1893); R. Ellis, A Commentary on Catullus (Oxford, 1876).

7 T. Beasley, 'A Homeric echo in Catullus 51', CQ 62 (2012), 862-3; A. Pardini, 'A Homeric formula in Catullus (c. 51. 11-12 gemina teguntur lumina nocte)', TAPhA 131 (2001), 109-18; J.H. Dee, 'Iliad 1.4 f. and Catullus 64.152 f.: further considerations', TAPhA 111 (1981), 39-42; R.F. Thomas, 'On a Homeric reference in Catullus', AJPh 100 (1979), 475-6; J.E.G. Zetzel, 'A Homeric reminiscence in Catullus', AJPh 99 (1978), 332-3; A. Ronconi, Interpreti latini di Omero (Torino, 1973), 37-9; A. Luppino, 'Echi Omerici in Catullo', RFIC 93 (1965), 165-70; cf. E.H. Bateson, 'The central section of Catullus' Attis', Mnemosyne 68 (2015), 91-101; J.H. Gaisser, 'Introduction: themes in Catullan criticism (c.1950-2000)', in J.H. Gaisser (ed.), Oxford Readings in Classical Studies: Catullus (Oxford, 2007), 1-24, at 19; M.B. Skinner, 'Transactions with Catullus', CW 95 (2002), 435-8, at 437; J.B. Debrohun, 'Ariadne and the whirlwind of fate: figures of confusion in Catullus 64.149-57', CPh 94 (1999), 419-30, at 428 n. 27; W. Fitzgerald, Catullan Provocations: Lyric Poetry and the Drama of Position (Berkeley - Los Angeles - London, 1995), 199.

${ }^{8}$ Such an intentional reference, as far as I know, was suggested only by Clay (n. 2), 153, who called it 'general allusion', and by Syndikus (n. 4), 90 n. 66.

${ }^{9}$ Clay (n. 2).

${ }^{10}$ R.R. Nauta, 'Catullus 63 in a Roman context', Mnemosyne 57 (2004), 596-628.

11 B.-M. Näsström, The Abhorrence of Love: Studies in Rituals and Mystic Aspects in Catullus' Poem of Attis (Uppsala, 1989).
} 
2. Their longing is described in a similar way. Both of them are gazing at the sea, looking desperately for a trace of their homelands on the horizon: $\alpha$ viò $\rho$

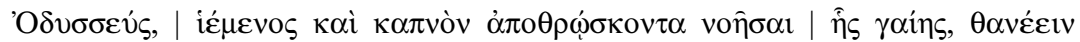


from his own country, longs to die', Od. 1.57-9); ubinam aut quibus locis te positam, patria, reor? | cupit ipsa pupula ad te sibi derigere aciem ('where then or in what region do I think your place to be, O my country? My eyeballs unbidden long




5.152-3); uisens lacrimantibus oculis ('looking out with streaming eyes', Catull. 63.48). In both instances the order of the words in the sentence is almost identical:

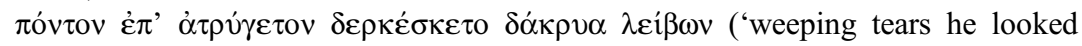
out over the barren water', Od. 5.158); maria uasta uisens lacrimantibus oculis ('looking out upon the waste seas with streaming eyes', Catull. 63.48).

3. Both Odysseus and Attis have their backs turned to the goddess, who dwells alone overseas, in a dark place surrounded by a thick forest: v̌ $\lambda \eta \delta \dot{\varepsilon} \sigma \pi \varepsilon \dot{\alpha} \varsigma \dot{\alpha} \mu \varphi \grave{i} \pi \varepsilon \varphi v ́ \kappa \varepsilon 1$ $\tau \eta \lambda \varepsilon \theta$ ó $\omega \sigma \alpha$ ('there was a growth of grove around the cavern', Od. 5.63); opaca siluis redimita loca deae ('the goddess' abodes, shadowy, forest-crowned', Catull. 63.3).

4. The goddess holds both of them in captivity: $\dddot{\mu} \mu \mathrm{t} v \dot{\alpha} v \alpha \dot{\alpha} \gamma \kappa \eta \mid$ | by constraint', $O d$. 4.557-8, 5.14-5, 17.142-3; cf. हैрvкع in Od. 1.14, 9.29;

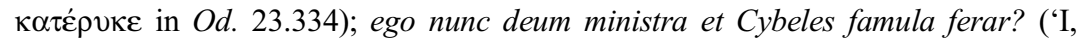
shall I now be called-what? a handmaid of the gods, a ministress of Cybele?', Catull. 63.68); mea libere nimis qui fugere imperia cupit ('him who would be too free, and run away from my sovereignty', Catull. 63.80); ibi semper omne uitae spatium famula fuit ('there always for all his lifetime was he a handmaid', Catull. 63.90).

5. Both Odysseus and Attis (at least potentially) are in an erotic relationship with the

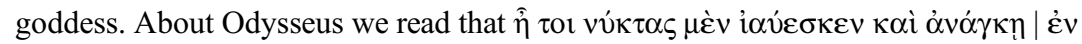

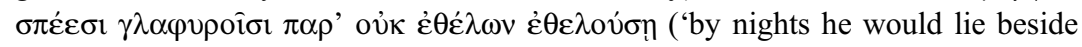
her, of necessity, in the hollow caverns, against his will, by one who was willing',

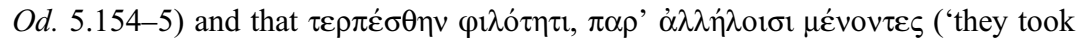
their joy of love, abiding each by the other's side', $O d$. 5.227). As for the relationship between Cybele and Attis, some versions of the myth suggest its erotic nature. ${ }^{12}$ Besides, the castration itself, in the context of the relationship between a man and a goddess, suggests its erotic, though perverse, character. ${ }^{13}$

6. Both of them were initially fascinated by the goddess. In the Odyssey (a point easy


nymph was no longer pleasing to him', $O d$. 5.153).

Though Fedeli suggests that we are dealing here with a 'profonda diversità della situazione', ${ }^{14}$ Catullus' Attis resembles Odysseus at Ogygia as no other protagonist does in

\footnotetext{
12 In Diodorus Siculus' euhemeristic interpretation of the myth, Cybele is inseminated by Attis:


with Attis: $\tau 0 \hat{v} \pi \alpha \imath \delta$ ò facie spectabilis, Attis | turrigeram casto uinxit amore deam (Fast. 4.223-4).

13 See W. Burkert, Ancient Mystery Cults (Cambridge, Mass. and London, 1987), 107; V. Panoussi, 'Ego Maenas: Maenadism, marriage, and the construction of female identity in Catullus 63 and 64', Helios 30 (2003), 101-26, at 110.

${ }^{14}$ Fedeli (n. 4), 52.
} 
ancient literature. This analogy goes deeper if we realize that the parallel elements between Carmen 63 and the Odyssey do not appear in the other versions of the myth of Attis and Cybele: nowhere else does Attis sit crying at the seashore, nowhere else is he longing for his homeland, and nowhere else does he have Cybele behind his back, who is keeping him in captivity. We can accept then that Carmen 63 presents Attis' situation on Cybele's mountain as analogous to that of Odysseus on Ogygia. Now this observation makes some of the hitherto proposed interpretations of Carmen 63 more probable.

\section{ATTIS' JOURNEY TO CYBELE AS ODYSSEUS' INVERTED NOSTOS}

At first glance we can observe that Attis' story is a kind of reversal of Odysseus' fate. ${ }^{15}$ What is more, Odysseus left Ogygia on a raft, a $\sigma \chi \varepsilon \delta i \eta \eta$, which is (if we interpret the word ratis literally as it stands in the text) Attis' means of transport, and is already mentioned in the poem's first verse, to the shores of Cybele: super alta uectus Attis celeri rate maria ('Borne in his swift bark/raft over deep seas', Catull. 63.1). It is important to note that the motif of the 'reversal' of Odysseus' nostos appears in Catullus' Carmen 101. Catullus commences the poem about the poet's 'pilgrimage' to the tomb of his brother at Rhoeteum in the Troad (in close proximity to Mt Ida!) with the words $(101.1-2)$ :

multas per gentes et multa per aequora uectus aduenio has miseras, frater, ad inferias.

Wandering through many countries and over many seas I come, my brother, to these sorrowful obsequies.

Scholars have noticed here a reference to the first words of the Odyssey (1.1-4): ${ }^{16}$

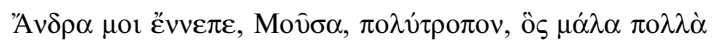

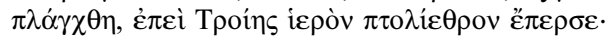

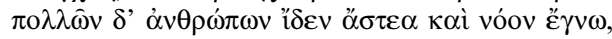

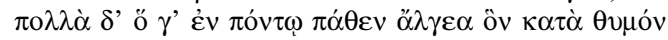

Tell me, Muse, of the man of many ways, who was driven far journeys, after he had sacked Troy's sacred citadel. Many were they whose cities he saw, whose minds he learned of, many the pains he suffered in his spirit on the wide sea.

For Catullus, therefore, the journey from Italy to Troy appears to be an inversion of Odysseus' journey from Troy to Ithaca-'a backward Odyssey, an anti-nostos' ${ }^{17}$ On

\footnotetext{
15 This inversion of themes did not escape the attention of scholars: Clay (n. 2), 153; Rubino (n. 5), 168.

16 J.E.G. Zetzel, 'Catullus, Ennius, and the poetics of allusion', in J.H. Gaisser (ed.), Oxford Readings in Classical Studies: Catullus (Oxford, 2007), 198-216, at 202; G.B. Conte, 'Poetic memory and the art of allusion (on a verse of Catullus and one of Virgil)', in J.H. Gaisser (ed.), Oxford Readings in Classical Studies: Catullus (Oxford, 2007), 167-76, at 174; C. Nappa, 'Catullus and Vergil', in M.B. Skinner (ed.), A Companion to Catullus (Malden, MA, 2007), 377-98, at 392; P. Green, The Poems of Catullus. A Bilingual Edition (Berkeley, 2005), 266; Nauta (n. 10), 624 n. 94; A. Feldherr, 'Non inter nota sepulcra: Catullus 101 and Roman funerary ritual', ClAnt 19 (2000), 209-31, at 215, 218 n. 30, 224, 227; G.B. Conte, Memoria dei poeti e sistema letterario: Catullo, Virgilio, Ovidio, Lucano (Torino, 1974), 6.

${ }^{17}$ Zetzel (n. 16), 202; Fitzgerald (n. 7), 187.
} 
this basis (but also on the basis of references to the Odyssey in Carmina 65 and 68), in a perhaps exaggerated way, Clay stated: 'The inversion of the Troy theme plays an important role in Catullus' private "mythology"., 18

\section{CONJUGAL CONNOTATIONS OF CARMEN 63}

Scholars have long noticed that Carmen 63 occupies a place among Catullan poems in which the central theme is marriage. ${ }^{19}$ Although some have observed an exception in Carmen 63 and do not discern in it any elements related to the reality of marriage (but only the erotic aspect of the relationship between Attis and Cybele), ${ }^{20}$ most scholars have discerned motifs related to the reality of marriage in Carmen 63. Some detected the conjugal theme in Attis' escape from human marriage, ${ }^{21}$ while others suggested that it is the relationship between Attis and Cybele that constitutes a form of conjugal liaison. ${ }^{22}$ Reference to the Odyssey may shed light on this issue.

At the beginning of the poem, Odysseus' situation is depicted as follows (Od. 1.11-15):



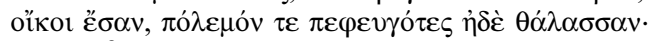



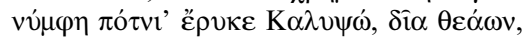



Then all the others, as many as fled sheer destruction, were at home now, having escaped the sea and the fighting. This one alone, longing for his wife and his homecoming, was detained by the queenly nymph Calypso, bright among goddesses, in her hollowed caverns, desiring that he should be her husband.

There is an explicit opposition between Penelope and the goddess Calypso. Odysseus is longing for his human wife while Calypso keeps him captive on her isle, desiring that he be her husband ( $\pi$ ó $\sigma ا \varsigma ;$ cf. Od. 9.30, 23.334). This opposition is fundamental to the whole concept of Odysseus' story-as we can see, it already appears in the first words in the poem, which refer directly to Odysseus' present situation (they immedi-

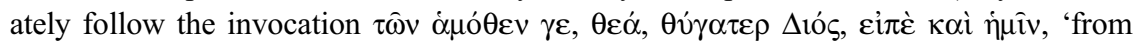
some point here, goddess, daughter of Zeus, speak, and begin our story', Od. 1.10). Bearing in mind the analogy between Odysseus' fate and that of Attis as well as the motif of the reversal of the plot (Attis travels in the opposite direction than

${ }^{18}$ Clay (n. 2), 153 n. 37.

19 E.g. Ellis (n. 6), 200; T.P. Wiseman, Catullan Questions (Leicester, 1969), 25; P.Y. Forsyth, 'The marriage theme in Catullus 63', CJ 66 (1970), 66-9, at 66; G.N. Sandy, 'Catullus 63 and the theme of marriage', AJPh 92 (1971), 185-95, at 187 n. 10; Clay (n. 2), 153 n. 38; Panoussi (n. 13), 101-2; M.B. Skinner, 'Authorial arrangement of the collection: debate past and present', in M.B. Skinner (ed.), A Companion to Catullus (Malden, MA, 2007), 35-53, at 44; Bateson (n. 7), 97; the conjugal context of Carmen 63 has been succinctly presented by Nauta (n. 10), 597.

${ }^{20}$ J. Glenn, 'The yoke of Attis', CPh 68 (1973), 59-61, at 60-1; Wiseman (n. 19), 22 and 25; E. Schäfer, Das Verhältnis von Erlebnis und Kunstgestalt bei Catull (Wiesbaden, 1966), 73-7; cf. Clay (n. 2), 154; Skinner (n. 19), 45; cf. n. 12 above.

21 E.g. Nauta (n. 10), 597, 605 and 607; Clay (n. 2), 145 and 151-2.

22 Forsyth (n. 19), 68; Sandy (n. 19), 194; T.P. Wiseman, Catullus and his World (Cambridge, 1985), 181; J. Ferguson, Catullus (Oxford, 1988), 34; cf. J. Granarolo, L'Euvre de Catulle: Aspects religieux, éthiques et stylistiques (Paris, 1967), 140; B. Arkins, Sexuality in Catullus (Hildesheim, 1982), 152; cf. Panoussi (n. 13), 103, 108, 110-13 and 122; Clay (n. 2), 154 n. 40. 
Odysseus), it is reasonable to assume that the way in which Odysseus' situation was presented by the author of the Odyssey sheds light on the content of Carmen 63 .

First, it can serve as an argument against the opinion that in Carmen 63 we are not dealing at all with any conjugal motif but only with an 'erotic' one. Second, the conjugal content of Carmen 63, in light of the reference to Odysseus' story, appears to be, in the first place, Attis' escape from human marriage (as if it were analogous to Odysseus' escape from Penelope). His new condition, consisting primarily of the fact that he deprived himself of the material and spiritual power of uir ('man'; see 63.6 sine uiro ['without manhood'], 63.17 euirastis ['you unmanned'], 63.69 uir sterilis ['a barren man']), should be interpreted as a forever-lost capacity for marriage and procreation.

\section{NÄSSTRÖM'S INTERPRETATION OF CARMEN 63}

In her 1989 monograph, ${ }^{23}$ Britt-Mari Näsström proposed that Attis' emasculation is an attempt to approach divinity and to attain immortality. Näsström seeks to demonstrate that in the history of religion sexuality is what particularly attaches man to 'this world', being thus the very core of human mortality. Religious castration, via a violent rejection of what constitutes the root of mortality, would be, in its essence, an act aimed at achieving a position beyond death. ${ }^{24}$ According to Näsström, the castration of Galli (of which Attis' emasculation constitutes a prototype) ${ }^{25}$ initially has such a feature. ${ }^{26}$ For her, this is how Attis' deed should be interpreted. ${ }^{27}$

Näsström's approach has barely been discussed by Catullan scholars. ${ }^{28}$ Now, a reference by Catullus to the Odyssey may serve as an argument in favour of interpreting Attis' emasculation as aimed at raising him above human mortality. The stay at Ogygia is the most difficult test of all tests Odysseus has been put to. Calypso promises to make

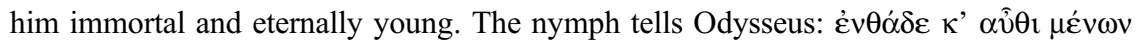


be the lord of this household and be an immortal', Od. 5.208); then, she says to Hermes:

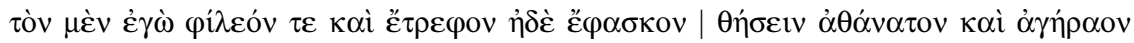
$\ddot{\eta} \mu \alpha \tau \alpha \pi \alpha \dot{\alpha} v \alpha$ ('and I gave him my love and cherished him, and I had hopes also that I could make him immortal and ageless all his days', Od. 5.135-6). Later, Odysseus returned, as we can feel not without pride, to Calypso's promise. To Arete, the queen

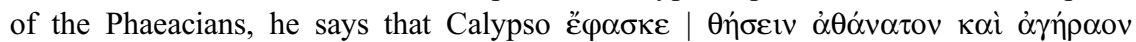
$\dddot{\eta} \mu \alpha \tau \alpha \pi \alpha ́ v \tau \alpha$ (Od. 7.256-7), and he repeats the same utterance to Penelope (Od. 23.335-6). Ogygia itself is reminiscent of Elysium, which has convincingly been argued by Anderson. ${ }^{29}$ What is important is that Calypso's divine immortality is explicitly opposed to Penelope's human mortality. Odysseus turns to Calypso with the words:


are immortal and ageless', $O d$. 5.218).

23 Näsström (n. 11).

24 Näsström (n. 11), 84.

25 Näsström (n. 11), 75.

26 Näsström (n. 11), 81.

27 Näsström (n. 11), 82 .

${ }^{28}$ See, however, the review of Näsström (n. 11) by K. Dowden, CR 41 (1991), 501-2 and Bateson (n. 7), 95 .

29 W.S. Anderson, 'Calypso and Elysium', CJ 54 (1958), 2-11, at 6. 
The fact that Catullus referred to the episode of Odysseus' stay at Ogygia can therefore support Näsström's suggestion that Attis' journey to Cybele and his emasculation were aimed at his being liberated from the chains of transience of this mortal life.

\section{ATTIS’ DEED AS AN ACT OF HUBRIS?}

Transgressing human mortality and ipso facto approaching immortal divinity was a constant postulate of ancient thought. Greek mythology is full of characters who wanted to overcome their human limitations and come closer to the divine. At the same time, paradoxically, in their attempts of this transgression one saw the greatest $\sin$-hubris. The wisdom of the ancient Greeks constantly warns us against attempts to transgress human limits. The famous aphorism $\gamma v \hat{\omega} \theta \mathrm{t} \sigma \alpha v \tau$ tóv, inscribed, according to Pausanias (10.24.1), in the Pronaos of the Temple of Apollo at Delphi, originally meant precisely this: 'Do not try to be like a god.' The gods look askance at human efforts of being 'like

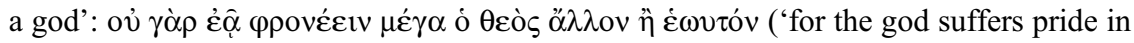
none but himself', Hdt. 7.10.55; cf. Hor. Carm. 1.3.37-40). The attempt to transgress ontological limitations most often ends in disaster in Greek mythology: Arachne, Actaeon, Bellerophon, Endymion, Lycaon, Niobe, Orion, Salmoneus, Tantalus, Thamyris and Tithonus are the most well-known examples of these failed attempts. Often, however, the consequence of hubris is not death but a metamorphosis, a degradation into some lower, degenerate state. The usurper not only does not become a god (or like a god) but also loses his/her human nature: Arachne, who challenged Athena in a weaving contest, was transformed into a spider; Actaeon, who saw Artemis naked, was transformed into a deer; Lycaon, testing Zeus to see whether he was truly omniscient, was transformed into a wolf; Niobe, who boasted to Leto of her progenitive superiority, was transformed into a stone; and, finally, Tithonus, the lover of Eos, granted with immortality but not with eternal youth, became a senile old man unable to die and was then transformed into a cicada.

If, as Näsström argues, the aim of Attis' journey and his emasculation was to achieve immortality, then it is justified to see in Carmen 63 also a story about hubris and its tragic consequences. Attis' words describing the dramatic consequences of his deed (63.69 ego pars mei, ego uir sterilis; 63.27 notha mulier) can be read as a description of his metamorphosis into an androgynous, odious ${ }^{30}$ being. Arguments for such an interpretation of Attis' metamorphosis are not only of a conceptual nature.

In the fifth book of the Odyssey there are two references to a relationship between a goddess and a mortal man and to the tragic consequences of these relationships. Calypso, having heard from Hermes of Zeus's order that she must let Odysseus leave her, utters words full of reproach (Od. 5.118-29):

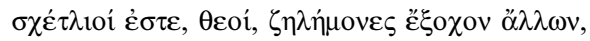

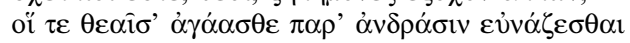

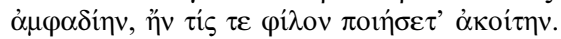



\footnotetext{
${ }^{30}$ For the Romans, the castration of the Galli appeared as something particularly disgusting and completely contradictory to Roman ethos. This issue was discussed in detail by Nauta (n. 10). It is also interesting that Lucretius treats the castration of Cybele's priests as punishment for their lack of pietas (2.614-17).
} 




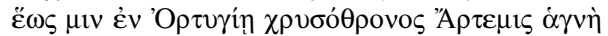

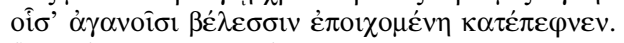

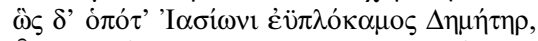

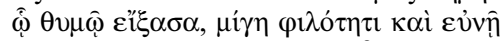





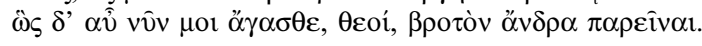

You are hard-hearted, you gods, and jealous beyond all creatures beside, when you are resentful toward the goddesses for sleeping openly with such men as each has made her true husband. So when Dawn of the rosy fingers chose out Orion, all you gods who live at your ease were full of resentment, until chaste Artemis of the golden throne in Ortygia came with a visitation of painless arrows and killed him; and so it was when Demeter of the lovely hair, yielding to her desire, lay down with Iasion and loved him in a thrice-turned field, it was not long before this was made known to Zeus, who struck him down with a cast of the shining thunderbolt. So now, you gods, you resent it in me that I keep beside me a man.

In both of the cases referred to by Calypso, those of Orion and Iasion, the gods' envy killed mortals who had entered into an erotic relationship with a goddess. The whole episode at Ogygia carries an implicit threat of the catastrophic consequences which would befall Odysseus if he decided to stay with Calypso. There is, however, more. The fifth book of the Odyssey starts with the words: 'Hஸ் $\delta$ ' $\dot{\varepsilon} \kappa \lambda \varepsilon \chi \varepsilon \dot{\varepsilon} \omega v \pi \alpha \rho$ '

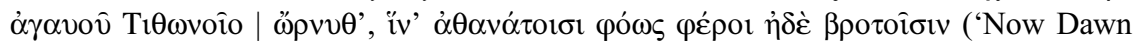
rose from her bed, where she lay by haughty Tithonus, carrying light to the immortal gods and to mortals', $O d$. 5.1-2). It is difficult not to see here an analogy to Calypso's lamentations. ${ }^{31}$ By mentioning, at the very beginning of the book, the person of Tithonus, who was granted immortality but not eternal youth, the poet indirectly informs the reader what precisely endangers Odysseus if he were to decide to stay with Calypso.

The close association between Attis' and Odysseus' stories may suggest that Catullus wanted the reader to see what happened to Attis as a consequence of his hubris, which is analogous to what had happened to Tithonus and what could have happened to Odysseus. In this light, referring to Attis as ibi semper omne uitae spatium famula fuit ('there always for all his lifetime was he a handmaid', Catull. 63.90) may have an ironic meaning.

Another argument in favour of the interpretation that Attis' story also has a dimension of hubris is that Carmen 63 begins with the words super alta uectus Attis celeri rate maria. Now, sailing, at least from the time of Hesiod, has unequivocal connotations with


on ships', Op. 236-7). ${ }^{32}$ In this context it is significant that Catullus' Carmen 64, which recounts the story of the ways in which gods and men separated (see especially Catull. 64.384-408), opens with a twin motif: Peliaco quondam prognatae uertice pinus | dicuntur liquidas Neptuni nasse per undas ('Pinetrees of old, born on the top of Pelion, are said to have swum through the liquid waters of Neptune', 64.1-2). That the ratis from the first verse of Carmen 63 may carry connotations of hubris may also be indicated by the fact that the vector of Odysseus' resignation from being a

31 I. de Jong, A Narratological Commentary on the Odyssey (Cambridge, 2001), 124.

32 Cf. Verg. Ecl. 4.31-3, 4.38-9; Arat. Phaen. 111; Ov. Met. 1.94-6; Tib. 1.3.37; Lucr. 5.1006; Hor. Carm. 1.3.21-4. 
goddess' lover and of his return to the mortal world is precisely the raft $(\sigma \chi \varepsilon \delta i \eta) .{ }^{33}$ As Odysseus departs on the raft from the island of Calypso, who tempted him with her promises of immortality and eternal youth, so Attis succumbs to the temptation to conquer immortality on Cybele's mountain after having sailed on the raft through 'deep seas'. ${ }^{34}$

Looking at these images through the perspective proposed by Näsström, we can see in Attis' castration an act of hubris, the consequence of which is a degradation into a state which is neither divine nor fully human (69 ego pars mei, ego uir sterilis ero? ['I part of myself, a barren man shall I be?']; 27 notha mulier ['a counterfeit woman']). Here Attis appears as an Odysseus who, having fled from Ithaca from Penelope and having remained in Ogygia, cut off all possibility of returning to human reality-the only reality where his human ego $(51,58,62,63,64,68,69,70,71)$ could be fulfilled ${ }^{35}$ - and experienced a fate similar to that of Tithonus. ${ }^{36}$

\section{CONCLUSION}

By juxtaposing analogous motifs in Carmen 63 and in the fifth book of the Odyssey we noticed that Catullus not only referred to the episode of Odysseus' sojourn at Ogygia but also made out of it a kind of matrix into which he fitted Attis' story. This observation provides, first of all, an argument in favour of the hypothesis that Carmen 63, as one of the carmina maiora, contains implicit conjugal content. Subsequently, it provides an argument in favour of the interpretation that the theme of marriage in the poem is, first of all, Attis' escape from human marriage and only secondly is it a quasi-conjugal relationship with Cybele. Finally, seeing Attis through the prism of a 'reversed Odysseus' strengthens the case for seeing Attis' emasculation as an act aiming at liberation from the chains of transience of mortal life. By taking this interpretative path, I have proposed to see in Attis' emasculation an act of hubris, with his metamorphosis into an androgynous being as its disastrous consequence.

University of Warsaw

JAN M. KOZLOWSKI jan.kozlowski@uw.edu.pl

\footnotetext{
${ }^{33}$ The famous description of the construction of the raft by Odysseus occupies (together with preparations made for it) thirty-four verses (Od. 5.228-62). The titles given in manuscripts to the fifth book of the Odyssey point to Odysseus' raft as a key element of the book's content, e.g.

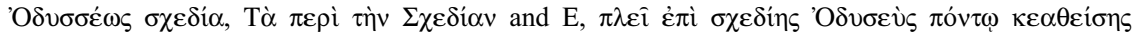
(Scholia in Homerum, Inscriptiones et hypothesis in Odysseam, inscr. 1-2).

${ }^{34}$ In this context it may also be significant that in the opening of Carmen 63 (super alta uectus Attis celeri rate maria, 1 ) as well as in the opening of Carmen 101 (multas per gentes et multa per aequora uectus, 1), which is a clear reference to the Odyssey (see note 16), the same participle, uectus, appears; cf. A. Perutelli, 'Il carme 63 di Catullo', Maia 48 (1996), 255-70, at 255.

${ }^{35}$ Ithaca is the only place in the world where Odysseus can be himself and live according to his human nature: see J.-P. Vernant, 'The refusal of Odysseus', in S.L. Schein (ed.), Reading the Odyssey. Selected Interpretive Essays (Princeton, 1996); Rubino (n. 5), 166. Attis' words addressed to his homeland, patria mei creatrix, patria o mea genetrix (Catull. 63.50), in light of the reference to the Odyssey, acquire an existential and eschatological meaning.

${ }^{36}$ This was, as it seems, the intention of Rubino (n. 5), 166: 'Such a fate, as Tithonus and the Attis of Catullus 63 discover too late, is the price of becoming the consort of a goddess.'
} 